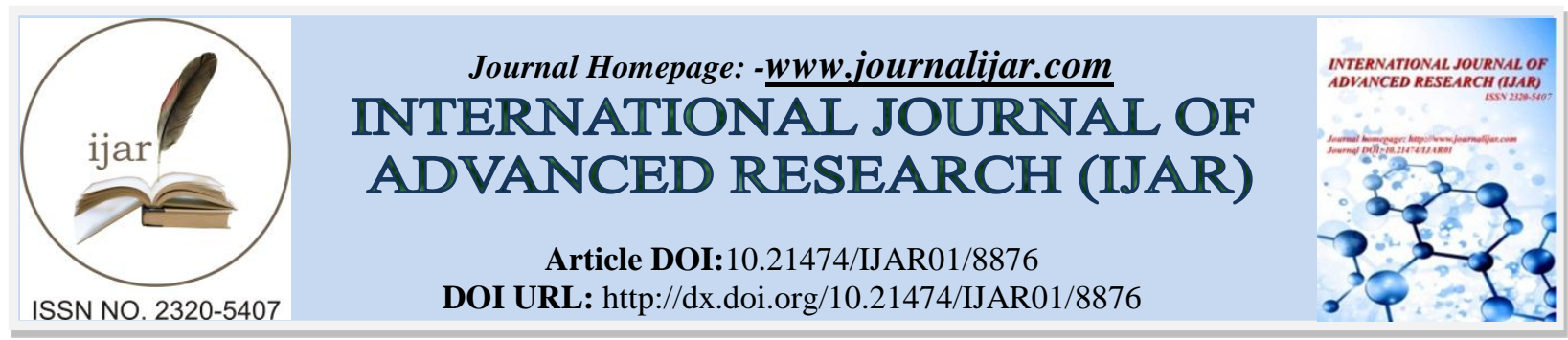

RESEARCH ARTICLE

\title{
AN EMPIRICAL STUDY ON EVIDENCE BASED PRACTICES AMONG PHYSIOTHERAPISTS IN INDIA.
}

\author{
Amjad Annethattil ${ }^{1}$, Manash Pratim Kashyap ${ }^{2}$ and P.C. Bhattacharyya ${ }^{3}$. \\ 1. MPT (Advance Physiotherapy in Neurology), PhD Scholar, Assam down Town University. \\ 2. North Eastern Regional Institute of Management. \\ 3. Professor HOD, Department of Medicine and Academic Co-coordinator Down Town Hospital, Guwahati, India.
}

\section{Manuscript Info}

\section{Manuscript History}

Received: 10 February 2019

Final Accepted: 12 March 2019

Published: April 2019

Key words:-

Stroke, Evidence based practice (EBP),

Outcome measures, Physiotherapist (PT).

\begin{abstract}
Background and Objectives: Evidence-Based Practice (EBP) is measured to be a corner stone of all health care, including physiotherapy. There is an explicit recognition that physiotherapy care should be underpinned by the philosophy of evidence-based practice which brings together best research evidence, clinical expertise, patient ethics values and beliefs and the information from practice contexts. The aim of the study was to find level of knowledge of EBP among physiotherapist practicing in stroke rehabilitation set up in India Method: Study Design: This was a cross sectional study. The sample size of the study was 901 . The target population of the study was physiotherapist across India. A literature review based English survey comprised of 40 questions was designed to explore participant's selfreported beliefs on evidence based practice (EBP) after completion of pilot survey. Data were analysed using SPSS statistical software, version 21.0.

Result and conclusion: There was a significant different between Indian physiotherapist's skills in evidence based practice. It is clear that evidence based stroke rehabilitation is more in south India. However, it seems low in North Zone. The education system i.e. Literature of Stroke specific outcome measures in day to day practice, research related to stroke specific outcome measures, study of advance tools and techniques are found to be significant difference among the Zones
\end{abstract}

Copy Right, IJAR, 2019,. All rights reserved.

\section{Introduction:-}

Evidence Based Practice (EBP) is considered to be an essential component of clinical service delivery in healthcare system $^{1}$. Physiotherapy as a profession is increasingly using evidence base to demonstrate best practice which is based on scientific principles and research $^{2}$ It has been known for some time now that the attitude and knowledge of physiotherapists is based on the use of evidence from research in forming clinical decisions since the 1980 's. ${ }^{2 .}$ EBP is the application of the best available evidence sourced from research findings into a clinical setting that ensures best practice ${ }^{3}$

Corresponding Author:-Amjad Annethattil ${ }^{1}$.

Address:-MPT (Advance Physiotherapy in Neurology), PhD Scholar, Assam down Town University. 
Evidence-based practice (EBP) has been defined as 'the conscientious, explicit and judicious use of current best evidence in making decisions about the care of individual patients' (Sackett et al., 2000, p.1) Effective treatment by clinicians in stroke rehabilitation should be based on appropriate evidence resulting in clinicians selecting best techniques that optimize and improve patients health outcomes.

EBP in physiotherapy has increased demand for the use of reliable and valid outcome measures for evaluation of physiotherapy treatment. ${ }^{4}$ The need of evidence based physiotherapy practice in physical therapy was recognized earlier (e.g., Campbell, 1970; Hislop, 1975), and has been repeated by many authors (e.g. Bohannon and LeVeau, 1986; Piper, 1991 Despite the clear benefits of EBP, it is apparent that India has shown inconsistency in following this practice.

As the second largest populated country in the world, India is known for its large patient population and high prevalence of poverty and illiteracy rates ${ }^{5}$. Stroke is one of the leading causes of death and disability in India ${ }^{5}$. The estimated adjusted prevalence rate of stroke ranges from 84-262/100,000 in rural and 334-424/100,000 in urban areas. The incidence rate is $119-145 / 100,000$ based on the recent population based studies. ${ }^{5}$

There is generally lack of EBP principles being applied internationally around the globe which is apparent from surveys that were conducted. This reports consistent barriers such as lack of time, skills, organizational support and low priority in treating patients. This seems to be a common theme across other disciplines of healthcare professionals too. (Barnard and Wile2001 (UK); Jette et al., 2003 (USA); Kamwendo, 2002 (Sweden); Metcalf et al., 2000, 2001 (UK); Palfreyman et al., 2003 (UK)). Similar findings have been reported from other surveys of other health professionals: (Bennett et al., 2003) (occupational therapists, Australia); O'Donnell (2003) (primary healthcare professionals); Palfreyman et al., 2003 (nurses, UK); and Parahoo (2000) (nurses, Ireland). Over the past few years despite an increase in research in physiotherapy particularly in neurorehabilitation from 2004 to $2014^{6}$ there remains a worry about the process of translating research into clinical practice.

\section{Objective of the Study:}

The aim of the study was to find level of knowledge of EBP among physiotherapist practicing in stroke rehabilitation set up in India. Accordingly, the objective of the study was to find the level of knowledge about EBP among physiotherapist practicing in stroke rehabilitation set up in India.

\section{Material and Methods:- \\ Study Design:}

This was a cross sectional study. The sample size of the study was 901. The target population of the study was physiotherapist across India. Qualified physiotherapist with minimum of bachelor degree in physiotherapy working in stroke rehabilitation in physiotherapy clinics or Hospitals in India

The stratum of the study is as follows:

\begin{tabular}{|c|c|}
\hline Zone & Sample Size \\
\hline South & 413 \\
\hline North & 210 \\
\hline West & 193 \\
\hline East & 85 \\
\hline
\end{tabular}

The potential physiotherapists were approached. The questionnaires were generated as web page with informed consent and purpose of study explained. The questionnaires also mailed to the working physiotherapist with the purpose, instruction and consent form including personal information, knowledge of outcome measures/evidence based practice, issues or challenges facing in using outcome measures, background and treatment Approaches.

\section{Survey Questionnaire:}

A literature review based English survey comprised of 40 questions was designed to explore participant's selfreported beliefs on EBP after completion of pilot survey. 
Data Analysis: Data were analysed using SPSS statistical software, version 21.0. Descriptive statistics were done to determine response frequencies and percentages. The statistical test chi-square for categorical, ANOVA for different comparison of groups are applied for the study.

\section{Results and Discussion:-}

Table 1:-Comparison Chart

\begin{tabular}{|c|c|c|c|c|c|}
\hline Variable & \multicolumn{2}{|l|}{ South } & West & East & $\begin{array}{l}\text { p- } \\
\text { Value }\end{array}$ \\
\hline \multicolumn{6}{|l|}{ Gender } \\
\hline Male & $306(52.9 \%)$ & $\begin{array}{l}115(19.9 \\
\%)\end{array}$ & $107(18.5 \%)$ & $\begin{array}{l}50(8.7 \\
\%)\end{array}$ & - \\
\hline Female & $107(33.1 \%)$ & $\begin{array}{l}95(29.4 \\
\%)\end{array}$ & $86(26.6 \%)$ & $\begin{array}{l}35 \\
(10.8 \% \\
)\end{array}$ & - \\
\hline \multicolumn{6}{|l|}{ Experience (in Years) } \\
\hline$<3$ & $\begin{array}{l}15 \\
(31.9 \%)\end{array}$ & $17(36.2 \%)$ & $9(19.1 \%)$ & $\begin{array}{l}6 \\
(12.8 \% \\
)\end{array}$ & - \\
\hline $3-5$ & $\begin{array}{l}84 \\
(46.7 \%)\end{array}$ & $61(33.9 \%)$ & $19(10.6 \%)$ & $\begin{array}{l}16(8.9 \\
\%)\end{array}$ & - \\
\hline 6-10 & $\begin{array}{l}154 \\
(47.1 \%)\end{array}$ & $73(22.3 \%)$ & $67(20.5 \%)$ & $\begin{array}{l}33 \\
(10.1 \% \\
)\end{array}$ & - \\
\hline 11- 20 & $\begin{array}{l}124 \\
(53.9 \%)\end{array}$ & $34(14.8 \%)$ & $51(22.2 \%)$ & $\begin{array}{l}21 \\
(9.1 \%)\end{array}$ & - \\
\hline$>20$ & $\begin{array}{l}36 \\
(30.8 \%)\end{array}$ & $25(21.4 \%)$ & $47(40.2 \%)$ & $\begin{array}{l}9 \\
(7.7 \%)\end{array}$ & - \\
\hline \multicolumn{6}{|l|}{ Professional Qualification } \\
\hline Bachelors & $\begin{array}{l}288 \\
(50.4 \%)\end{array}$ & $107(18.7 \%)$ & $124(21.7 \%)$ & $\begin{array}{l}52 \\
(9.1 \%)\end{array}$ & - \\
\hline 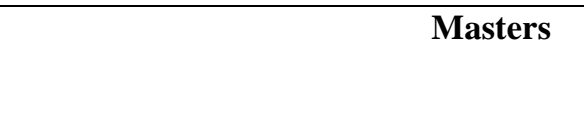 & $\begin{array}{l}118 \\
(39.3 \%)\end{array}$ & $90(30.0 \%)$ & $60(20.0 \%)$ & $\begin{array}{l}32 \\
(10.7 \% \\
)\end{array}$ & - \\
\hline PhD & $7(23.3 \%)$ & $13(43.3 \%)$ & $9(30.0 \%)$ & $\begin{array}{l}1 \\
(3.3 \%)\end{array}$ & - \\
\hline \multicolumn{6}{|l|}{ Read the Literature Stroke } \\
\hline Never & $0(0.00 \%)$ & $3(1.40 \%)$ & $0(0.00 \%)$ & $4(4.70 \%)$ & 0.54 \\
\hline Rarely & $9(2.20 \%)$ & $11(5.20 \%)$ & $0(0.00 \%)$ & $\begin{array}{l}14(16.50 \\
\%)\end{array}$ & $\begin{array}{l}< \\
0.001\end{array}$ \\
\hline Once in Month & $\begin{array}{l}67 \\
(16.2 \%)\end{array}$ & $67(31.90 \%)$ & $18(9.30 \%$ & $\begin{array}{l}35 \\
(41.20 \%)\end{array}$ & $\begin{array}{l}<0.00 \\
1\end{array}$ \\
\hline Every Week & $\begin{array}{l}337 \\
(81.60 \%)\end{array}$ & $\begin{array}{l}129(61.40 \% \\
)\end{array}$ & $\begin{array}{l}175(90.70 \\
\%)\end{array}$ & $\begin{array}{l}32(37.60 \\
\%)\end{array}$ & $\begin{array}{l}<0.00 \\
1 \\
\end{array}$ \\
\hline Evidence Based Stroke Rehabilitation & $\begin{array}{l}24.89 \pm 1.4 \\
2\end{array}$ & $19.5 \pm 2.14$ & $\begin{array}{l}26.37 \pm 1.7 \\
4\end{array}$ & $\begin{array}{l}21.51 \pm 2.2 \\
1\end{array}$ & $\begin{array}{l}<0.00 \\
1\end{array}$ \\
\hline \multicolumn{6}{|l|}{ Methods of Practicing } \\
\hline Bobath/NDT & $\begin{array}{l}387(45.53 \\
\%)\end{array}$ & $\begin{array}{l}210(45.36 \% \\
)\end{array}$ & $\begin{array}{l}187(16.95 \\
\%)\end{array}$ & $\begin{array}{l}66 \\
(4.79 \%) \\
\end{array}$ & $\begin{array}{l}< \\
0.001 \\
\end{array}$ \\
\hline PNF/Brunnstorm & $\begin{array}{l}391(45.95 \\
\%)\end{array}$ & $\begin{array}{l}210(45.65 \% \\
)\end{array}$ & $\begin{array}{l}189(17.17 \\
\%)\end{array}$ & $61(4.45 \%)$ & $\begin{array}{l}< \\
0.001\end{array}$ \\
\hline Davies & $\begin{array}{l}381(45.14 \\
\%)\end{array}$ & $\begin{array}{l}210(45.36 \% \\
)\end{array}$ & $\begin{array}{l}187(17.05 \\
\%)\end{array}$ & $66(4.81 \%)$ & $\begin{array}{l}< \\
0.001 \\
\end{array}$ \\
\hline Carr and Shepherd & $\begin{array}{l}397(46.60 \\
\%)\end{array}$ & $210(46.15 \%$ & $\begin{array}{l}186(16.96 \\
\%)\end{array}$ & $59(4.32 \%)$ & $\begin{array}{l}< \\
0.001\end{array}$ \\
\hline
\end{tabular}




\begin{tabular}{|c|c|c|c|c|c|}
\hline Task Oriented Approach & $\begin{array}{l}387(45.80 \\
\%)\end{array}$ & $210(45.85 \%$ & $\begin{array}{l}190(17.38 \\
\%)\end{array}$ & $58(4.26 \%)$ & $\begin{array}{l}< \\
0.001\end{array}$ \\
\hline Others & $\begin{array}{l}391(46.22 \\
\%)\end{array}$ & $210(46.15 \%$ & $\begin{array}{l}184(16.87 \\
\%)\end{array}$ & $61(4.48 \%)$ & $\begin{array}{l}< \\
0.001\end{array}$ \\
\hline Additional training & $\begin{array}{l}381 \\
(92.30 \%)\end{array}$ & $\begin{array}{l}175 \\
(83.30 \%)\end{array}$ & $\begin{array}{l}173 \\
(89.60 \%)\end{array}$ & $\begin{array}{l}62 \\
(72.90 \%)\end{array}$ & $\begin{array}{l}< \\
0.001\end{array}$ \\
\hline Follow the Physiotherapy Guidelines & $\begin{array}{l}364 \\
(88.10 \%) \\
\end{array}$ & $\begin{array}{l}177 \\
(84.30 \%)\end{array}$ & $\begin{array}{l}187 \\
(96.90 \%) \\
\end{array}$ & $\begin{array}{l}65 \\
(76.50 \%) \\
\end{array}$ & $\begin{array}{l}< \\
0.001\end{array}$ \\
\hline Stroke patient needs hands on training & $\begin{array}{l}4.69 \pm 0.55 \\
4\end{array}$ & $3.67 \pm 0.939$ & $\begin{array}{l}3.99 \pm 0.89 \\
3\end{array}$ & $\begin{array}{l}4.76 \pm 0.50 \\
3\end{array}$ & $\begin{array}{l}<0.00 \\
1\end{array}$ \\
\hline $\begin{array}{l}\text { Incorporate concept of Motor Learing from } \\
\text { Current Literature }\end{array}$ & $\begin{array}{l}4.77 \pm 0.45 \\
7\end{array}$ & $3.88 \pm 0.907$ & $4.7 \pm 0.531$ & $\begin{array}{l}3.84 \pm 0.84 \\
3\end{array}$ & $\begin{array}{l}< \\
0.001\end{array}$ \\
\hline
\end{tabular}

From the above table it is observed that $64.2 \%$ male and $35.8 \%$ female. In case of male, $52.9 \% 19.9 \%, 18.5 \%$ and $8.7 \%$ PT's from South, North, West and East zone respectively. However, female PT's are most from the south zone i.e. $33.1 \%$ and $29.4 \%, 26.6 \%$ and $10.8 \%$ are from North, west and East zone respectively.

In case of less than 3 years PhysioTherapy experience, $36.2 \%$ of the PT's from north followed by South (31.9\%), West (19.1\%) and East (12.8\%). In between 3 to 5 years PT experience, $46.7 \%, 33.9 \%, 10.6 \%$ and $8.9 \%$ PT's are from south, North, West and East respectively. Again, between 6 to 10 years there are 47.1\% PT's are from South where as $22.3 \%, 20.5 \%$ and $10.1 \%$ PT's from North, West and East respectively. Again, it is seen that 11 to 20 years experience PT's most from South zone (53.9\%) then west zone has $22.2 \%$. North zone and South Zone experience PT's are $14.8 \%$ and $9.1 \%$ respectively. In the category, experience more than 20 years, it is observed that $40.2 \%$ PT's from west zone where as 30.8\% experience PT's from South zone. North zone and east zone has $21.4 \%$ and $7.7 \%$ respectively.

Professional qualifications of PT's are broadly classified as bachelor, masters and Ph.D. In the category of bachelor, south zone has $50.4 \%$ while western zone has $21.7 \%$. It is also seen that $21.7 \%$ and $18.7 \%$ PT's belong from west and north zone respectively. Post graduate PT's are mostly from South zone i.e. 39.3\% while North zone have $30.0 \%$. West and east zone have $20.0 \%$ and 10.75 respectively. In the stratum of $\mathrm{PhD}$, it is study that north zone have $43.3 \%$ PT's which is followed by west zone (30\%), south zone $(23.3 \%)$ and east zone $(3.3 \%)$.

In the study of PT's read the literature, it is observed that most literature studied at west zone i.e. $90.70 \%$ in every week. However, south, north and east zone have $81.60 \%, 61.40 \%$ and $37.60 \%$ respectively. The literature read by PT's in different zone is found to be significant at $5 \%$ level of significance.

Evidence based stroke rehabilitation mostly done in west zone which mean is 26.37. In south zone, the mean EBS rehabilitation score is 24.89. However, the least mean EBS rehabilitation score 19.5 found in North zone. In East zone mean EBS rehabilitation score is 21.51. The difference among the zone is found to be significant at $5 \%$ level of significance.

PT's different method adopt in practicing. The methods bobath/NDT, PNF/Brunstorm, carr and shepherd is mostly exercised by south zone and it is followed by north, west and East zone respectively. However, the method davies and task oriented approach is mostly exercised by North Zone PT's. Exercise of all the methods considered under the study is found to be significant among the Zones.

Additional training after Graduation among the PT's of different zone found to be significant. It is examined that $92.30 \%$ South zone PT's received additional training, where as $89.60 \%$ PT's from west zone. In North zone and east zone PT's obtain additional training is $83.30 \%$ and $72.90 \%$.

In west zone, 96.90\% PT's from West zone follow the Physiotherapy guidelines while $88.10 \%$ from south zone. In other hand, it is seen that $84.30 \%$ and $76.50 \%$ of PT's follow the guidelines from north and east zone respectively. There is a significance difference among the zone to PT's following the physiotherapy guideline but there is no uniformity in following guidelines in stroke rehabilitation 
From the above table, it is observed that the mean score is 4.76 . This means physiotherapist beliefs that stroke patient needs more hands on training in east zone than south zone whose mean score is 4.69. However, physiotherapist in North zone beliefs lesser hand on training while treating a stroke patient, the mean score is 3.67. The West zone physiotherapist requires more hands on training than north zone due to the mean score is 3.99. It is also seen that there is significantly difference among the zones in stroke patient's hands on training.

The above table furnish that in south zone PT's are mostly incorporating concept of motor Learing from current literature since mean score is 4.77 where as east zone is less i.e. 3.84. S imilarly, the north zone and west zone is 3.88 and 4.7 respectively.

\section{Conclusion:-}

The following conclusions are furnish in the study

1. It is seen that there is a significant different between Indian physiotherapist's skills i.e. South, North, East and West in case of evidence based practice.

2. From the above table it is clear that evidence based stroke rehabilitation is more in south. However, it seems low in North Zone.

3. The education system i.e. Literature of Stroke specific outcome measures in day to day practice, research related to stroke specific outcome measures, study of advance tools and techniques are found to be significant difference among the Zones.

There was a significant difference between Indian physiotherapist's skills and knowledge of evidence-based practice and the extent of the use of standardized outcome measures in stroke rehabilitation in India. The education system; the practice settings and the environments are different from place to place. There is neither a standardized of practice in stroke rehabilitation nor a unified stroke protocol or guidelines. This study findings can be generalized into wider populations and the results can be integrated and extracted for further studies in the rehabilitation area as well as other medical and allied health scenarios.

\section{References:-}

1. M. Harrison. Evidence based practice: practice based evidence. Physiotherapy theory and practice. 1996, 12, 129-30

2. B E Gibbson, DK Martin. Qualitative Research and Evidence- based Physiotherapy practice. Physiotherapy. 2003. 89(6), 350-58

3. C Bithell. Evidence- based Physiotherapy : Some thoughts on best evidence. Physiotherapy. 2000. 86(2), 58-59.

4. Hanna, S. E., Russell, D. J., Bartlett, D. J., Kertoy, M., Rosenbaum, P. L. \& Wynn, K. (2007) Measurement practices in pediatric rehabilitation: a survey of physical therapists, occupational therapists, and speechlanguage pathologists in Ontario. Physical \& Occupational Therapy in Pediatrics, 27 (2), 25-42

5. Das SK, Banerjee TK, Biswas A et al. A prospective community based study of stroke in Kolkata, India. Stroke 2007; 38:906-10 3)

6. What Is the Evidence for Physical Therapy Post stroke? A Systematic Review and Meta-Analysis Janne Marieke Veerbeek, Erwin van Wegen, Roland van Peppen, PLoS One 2014; 9(2): e87987. 